J. Clin. Chem. Clin. Biochem.

Vol. 24, 1986, pp. 597-600

(C) 1986 Walter de Gruyter \& Co.

Berlin - New York

\title{
Influence of Neuraminidase Treatment on the Electrophoretic Behaviour of Angiotensin Converting Enzyme from Human Tissues
}

\author{
By S. Scharpé, M. van Sande, D. Hendriks
}

Faculty of Medicine - Units of Clinical Biochemistry and Urology, University of Antwerp, Belgium and

\section{Y. Kasahara}

Fujirebio Inc., Tokyo, Japan

(Received November 22, 1985/February 10, 1986)

Summary: Angiotensin converting enzyme (dipeptidyl carboxypeptidase, kininase II; EC 3.4.15.1), is a membrane bound glycoprotein, playing an important role in the renin-aldosterone system. The enzyme contains a carbohydrate moiety, consisting of fucose, mannose, galactose, $\mathrm{N}$-acetylglucosamine and $\mathrm{N}$ acetylneuraminic acid. Treatment with neuraminidase (EC 3.2.1.18) removes sialic acid from the molecule. The influence of this treatment on the electrophoretic mobility of the enzyme was studied in 29 human tissues and body fluids. Results obtained showed differences in the sialic acid content of the enzyme in the tissues examined.

Einfluß von Neuraminidase-Behandlung auf das elektrophoretische Verhalten von Angiotensin Converting Enzyme aus menschlichen Geweben

Zusammenfassung: Angiotensin Converting Enzyme (Dipeptidyl carboxypeptidase, Kininase II; EC 3.4.15.1) ist ein membrangebundenes Glykoprotein, das eine wichtige Rolle im Renin-Aldosteron-System spielt. Der Kohlenhydratanteil enthält Fucose, Mannose, Galaktose, N-Acetylglucosamin und N-Acetylneuraminsäure. Behandlung mit Neuraminidase (EC 3.2.1.18) spaltet Sialinsäure vom Molekül ab. Der Einfluß dieser Behandlung auf die elektrophoretische Beweglichkeit des Enzyms wurde in 29 Geweben und Körperflüssigkeitên vom Menschen bestimmint. Die Ergebnisse weisen auf Unterschiede im Sialinsäuregehalt des Enzyms in den untersuchten Geweben hin.

\section{Introduction}

Angiotensin converting enzyme (EC 3.4.15.1) or kininase II is widely distributed in the body. In a previous paper (1), we studied the electrophoretic behaviour of converting enzyme in agar and polyacrylamide gel electrophoresis in a variety of human tissue homogenates, and we found differences in electrophoretic mobility and extremely different enzyme catalytic activities, depending on the tissues studied. Surprisingly, human benign prostatic hyperplasia showed the highest angiotensin converting enzyme activity, whereas normal and adenocarcinomatous prostate tissue yielded lower catalytic activities. Several tissues from the digestive tract, in particular appendix and ileum showed also a high converting enzyme activity.

It has been shown by several authors, mostly in animal tissues, that angiotensin converting enzyme is a glycoprotein, with a rather important carbohydrate moiety. For instance the carbohydrate content of converting enzyme from rabbit lung is estimated to be $26 \%$ (2), composed of hexose, glucose, mannose, galactose, $\mathrm{N}$-acetylglucosamine and $\mathrm{N}$-acetyl-neuraminic acid. 
Using agar gel electrophoresis, we studied the behaviour of converting enzyme in human tissue homogenates before and after removal of sialic by treatment with neuraminidase (EC 3.2.1.18).

\section{Materials and Methods}

Reagents

Agar Noble was from Difco, Detroit, Mich., USA. Hippuricase (EC 3.5.1.14) and the enzyme substrate $p$-hydroxyhippuryl- $L$ His- $L$-Leu were obtained from Fujirebio, Tokyo, Japan.

Nonidet P 40 was from LKB, Bromma, Sweden.

Neuraminidase was purchased from Sigma, St. Louis, Missouri, USA.

Octyl- $\beta$ - $D$-glucopyranoside was from Calbiochem-Behring, La Jolla, California, USA.

Captopril (SQ 14225) was a generous gift from Squibb Belgium.

All other chemicals of high purity were obtained from Merck, Darmstadt, FRG. In all assays deionized water was used.

Human tissues and body fluids

\section{Biological fluids}

Serum was obtained from blood bank donors, sperm from healthy donors and prostatic fluid from vasectomized individuals. All fluids were chilled in liquid nitrogen and stored at $-80^{\circ} \mathrm{C}$ as rapidly as possible.

\section{Tissues}

The following were obtained by open surgery. Prostate (from patients with prostatic carcinoma or benign prostatic hyperplasia), normal prostate (from patients with bladder cancer), kidney (cortex and medulla), xanthogranulomatous kidney, bladder, testis, ductus deferens, seminal vesicles, lung, sigmoid (normal and cancer), stomach (antrum and ulcus), spleen, ileum, gall bladder, appendix, rectum, colon transversum, liver, thyroid, polynodular goitre, vena saphena magna, ovary, breast cancer and bone marrow. The tissues were stored as soon as possible in liquid nitrogen.

For each biological fluid or tissue, at least two specimens from different patients were examined.

\section{Tissue preparation}

Tissues were homogenized by grinding in an Elvchjem glass homogenizer with a teflon pestle, either by adding one drop Nonidet P 40 per $200 \mathrm{mg}$ tissue or according to the method of Lazo \& Quinn (3), using a $30 \mathrm{mmol} / 1$ solution of octyl- $\beta-D$ glucopyranoside. After centrifugation at $50000 \mathrm{~g}$ for $30 \mathrm{~min}$ at $4^{\circ} \mathrm{C}$ in a MSE-cryofuge, the supernate was used for electrophoresis, before and after neuraminidase treatment.

\section{Neuraminidase treatment}

Neuraminidase (3.4 mg, 2.5 units) was dissolved in $100 \mu 1100$ $\mathrm{mmol} / \mathrm{l}$ potassium phosphate buffer ( $\mathrm{pH}$ 5.0). This solution (10 $\mu$ ) was incubated for $5 \mathrm{~h}$ at $37^{\circ} \mathrm{C}$ with an equal volume of homogenate.

\section{Electrophoresis}

Agar gel electrophoresis was carried out according to Wieme (4). The methodology followed is described in our previous paper (1), together with the detection of the enzyme activity (5).

\section{Results and Discussion}

For the tissues and body fluids studied, we measured the distance between the maxima of the major peak before and after neuraminidase treatment. As shown in our previous paper (1), agar gel electrophoresis reveals multiple forms of the converting enzyme. In this study we examined only the mobility of the major peak of the enzyme. Results are represented in figure 1. An example of the angiotensin converting enzyme electrophoretic behaviour before and after neuraminidase treatment is represented for prostate (benign hyperplasia) tissue homogenate in figure 2.

Longer treatment with neuraminidase had no effect on the electrophoretic mobility of the major desialylated enzyme peak. Koheil \& Forstner (16) stated that after two to three hours desialylation was complete.

In the last 5 tissues from figure 1 we found no difference in electrophoretic behaviour before and after neuraminidase treatment.

The number of sialic acid residues cleaved from the converting enzyme molecule can only be calculated when working on purified enzyme. As the tissues at our disposal were obtained after open surgery, the quantity available made an enzyme purification impossible.

The method used gives very reproducible results. Treatment of 10 normal sera with neuraminidase showed the same relative migration rate; the maximum enzymatic activities were all located in the same slice of the agar gel cut in 10 slices between the migration of albumin and the point with zero mobility. The presence of carbohydrate residues in converting enzyme was first demonstrated with a pure preparation of converting enzyme from rabbit lung (7). The authors found glucose, mannose, galactose, Nacetylglucosamine and $\mathrm{N}$-acetylneuraminic acid. $O \bar{s} h$ ima et al. (8) showed that sialic acid can be removed by neuraminidase without affecting the catalytic properties of angiotensin converting enzyme. This was later confirmed by Conroy et al. (9), studying converting enzyme from canine lung which has a carbohydrate content of $17 \%$," but small amounts of sialic acid. 




Fig. 1. Change of electrophoretic mobility of angiotensin converting enzyme in agar gel after neuraminidase treatment is shown for 29 human tissues. Results are expressed by measuring the difference of relative mobility of the major peaks before and after neuraminidase treatment, and expressed as the fraction of the distance between albumin and the zero point of mobility taken arbitrarily as 1.00 . As can be seen from figure 2, taking the prostate enzyme as an example, relative mobility is 0.75 before and 0.35 after neuraminidase treatment. The difference in relative fractions is $\frac{0.75-0.35}{1.0}=0.4$

On the ordinate, the values can be read as a function of the arbitrarily chosen relative mobility range (from 0 to 1.00 ).

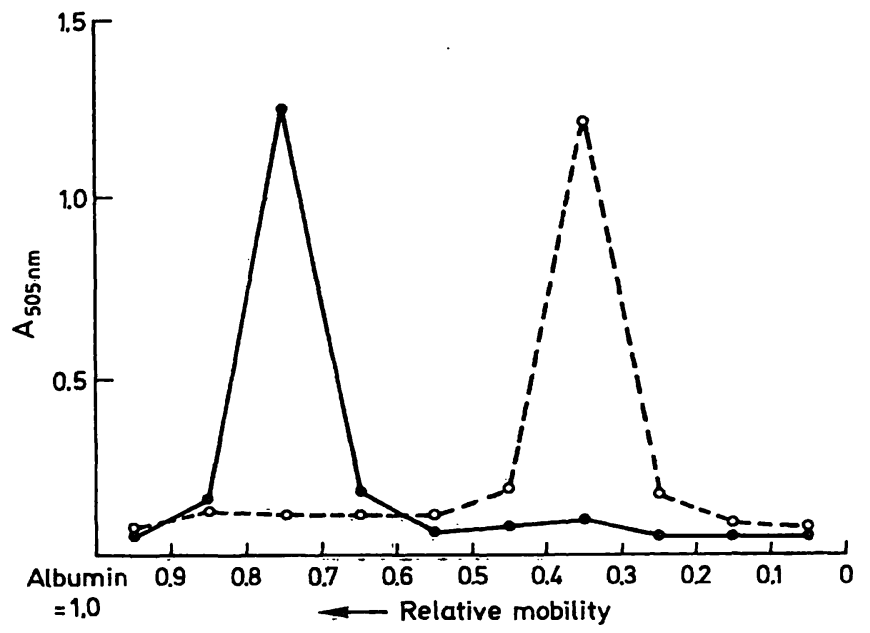

Fig. 2. Electrophoretic pattern of angiotensin converting enzyme in prostate (benign hyperplasia) homogenate, before $(0)$ and after neuraminidase treatment $(0)$.

Abscissa: electrophoretic mobility in agar gel.

Ordinate: absorbance of the quinoneimine dye.

The most important difference in electrophoretic behaviour after neuraminidase treatment was found by us in angiotensin converting enzyme from human serum, a fact which indicates the high content of sialic acid in the carbohydrate moiety of human serum angiotensin converting enzyme. This is in agreement with findings in several animal species. Das et al. (10), in a study on converting enzyme from rabbit lung and serum stated that converting enzyme from serum contains about three times more sialic acid than converting enzyme from lung. The authors suggested that the sialic acid content may be necessary to keep the converting enzyme of serum in the circulation and prevent its removal by the liver. However, in the guinea pig, the sugar moieties of angiotensin converting enzyme in lung and serum are similar (11) and the authors concluded that these findings lend support to the suggestion that lung may possibly serve as a source for the serum enzyme. These findings are exceptional, as it is accepted (12) that many of the galactosyl residues in the pulmonary enzyme are probably exposed as terminal non reducing units. The generally high content of sialic acid relative to galactose suggests that the serum enzyme contains few such exposed galactosyl residues. Morelle et al. (12) have observed that the serum survival time of a number of plasma glycoproteins is markedly shortened when their sialyl residues are removed. As a result of desialylation, galactose is exposed as a terminal non-reducing residue and serves as a specific determinant for recognition of the sialic acid deficient molecules by liver cells. A surface lectin capable of binding to galactosyl-terminating glycoproteins has been isolated from rabbit liver membrane (13).

Converting enzyme from human lung and kidney differ in their sialic acid content (14). Lung contains more acid forms, which confirms our findings.

It is not known why converting enzyme from benign prostatic hyperplasia and prostatic cancer seem to contain the same quantity of sialic acid. Yokoyama et al. (15), in a histological study of benign prostatic hyperplasia, stated that converting enzyme of benign prostatic hyperplasia, whose biochemical properties are very similar to those of human lung, is mainly located in the cystic component, suggesting dilated prostate acini may contain high converting enzyme activity. In contrast, little enzyme activity was found 
in the stromal tissue. In fact, this means that the glandular part of the prostate is the source of converting enzyme in the prostate, suggesting that in prostate carcinoma this part of the gland is not influenced by the cancer. Why the enzyme in normal prostate has a lower content of sialic acid, can only be explained by the hypothesis that dilated acini and lumen, which are not present in normal tissue, could be the origin of an angiotensin converting enzyme that is richer in sialic acid.

Takada et al. (16) isolated converting enzyme from human kidney and estimated the neutral sugar con- tent to be $13 \%$ per weight. This value is smaller than those of enzyme in lung tissue, so that our results corroborate these findings.

Complete explanation of our findings will require further studies on the carbohydrate moiety of angiotensin converting enzyme from these human tissues.

\section{Acknowledgement}

The authors wish to thank Prof. Dr. K. Van Camp and Dr. C. Van Camp for providing human tissues.

The skilful assistance of Mrs. M.P. Lommaert and Mrs. $E$. Enödi is highly appreciated.

\section{References}

1. van Sande, M., Scharpé, S., Neels, H. \& Kasahara, Y. (1985) J. Clin. Chem. Clin. Biochem. 23, 381-386.

2. Das, M. \& Soffer, R. L. (1975) J. Biol. Chem. 250, $6762-6768$.

3. Lazo, J. T. '\& Quinn, D. E. (1980) Arch. Biochem. Biophys. $102,68-71$.

4. Wieme, R. J. (1965) Agar Gel Electrophoresis, Elsevier, Amsterdam.

5. Kasahara, Y. \& Ashira, Y. (1981) Clin. Chem. 27, 1922-1925.

6. Koheil, A. \& Forstner, G. (1978) Biochim. Biophys. Acta $524,156-161$

7. Soffer, R. L., Reza, R. \& Caldwell, P. R. B. (1974) Proc. Natl. Acad. Sci. USA 71, 1720-1724.

8. Oshima, G., Nagawasa, K. \& Kato, J. (1976) J. Biochem. $80,477-483$.
9. Conroy, J. M., Hartley, J. L. \& Soffer, R. L. (1978) Biochim. Biophys. Acta 524, 403 =412.

10. Das, M., Hartley, J. L. \& Soffer, R. L. (1977) J. Biōl. Chem. 252, 1316-1319.

11. Lanzillo, J. J. \& Fanburg, B. Z. (1976) Biochim. Biophys. Acta $445,161-168$.

12. Morell, A. G., Gregoriadis, G., Scheimberg, I. H. (1971) J. Biol. Chem. 246, $1461-1467$.

13. Hudgin, R. L., Pricer, W. E., Ashwell, G., Stocker, R. J. \& Orell, A. G. (1974) J. Biol. Chem. 249, 5536- 5543.

14. Stewart, T. A., Weare, J. A. \& Erdös, G. E. (1981) Peptides 2, 145-152.

15. Yokoyama, M., Takada, Y., Iwata, H. \& Ochi, K., Takeuchi, M. \& Hiwada, K. (1982) J. U̇rol. 127, 368-370.

16. Takada, Y., Hiwada, K. \& Kokubu, T. (1981) J. Biochem. $90,1304-1319$.

Prof. Dr. S. Scharpé

Faculty of Medicine

Lab of Clinical Biochemistry

University of Antwerp

B-2610 Wilrijk 